\title{
Urban Water Management in Ancient Greece: Legacies and Lessons
}

D. Koutsoyiannis ${ }^{1 *}$, N. Zarkadoulas ${ }^{1}$, A. N. Angelakis ${ }^{2}$, and G. Tchobanoglous ${ }^{3}$

${ }^{1}$ Department of Water Resources, School of Civil Engineering, National Technical University of Athens, Heroon Polytechneiou 5, GR-15780 Zographou, Greece.

${ }^{2}$ National Foundation for Agricultural Research, Institute of Iraklio, 32A Kastorias str., 71307 Iraklio, Greece.

${ }^{3}$ Dept. of Civil and Environmental Eng., Univ. of California Davis, 662 Diego Place, Davis, CA 95616, U.S.A.

*Corresponding author (dk@itia.ntua.gr)

Abstract The evolution of urban water management in ancient Greece, beginning in Crete during the early Minoan period, resulted in a variety of remarkable developments in both the mainland and islands of Greece. Important developments include the implementation of hygienic living standards, advanced hydraulic technologies for water transportation, constructions for flood and sediment control, and sustainable urban water management practices, which can be compared to modern day practices. The evolution of water management was also related to the socio-political conditions. During oligarchic periods the emphasis was on the construction of large-scale hydraulic projects, whereas in democratic periods the focus of water management was on sustainable small scale, safe and cost efficient management practices, and institutional arrangements related to both the private and the public sectors. Such practices and institutions are relevant even today, as the water related problems of modern societies are not very different from those in antiquity.

Keywords (Subject headings) Aqueducts; Archaeology; Dams; History; Historic sites/Monuments; Hydraulic structures; Urban development; Water management; Water supply.

Submitted: January 2006; First revision: May 2006; Second revision: November 2006 


\section{Introduction}

Differences between the ancient Greek civilization with the earlier Mesopotamian and Egyptian civilizations are not confined to cultural or mental issues, but also extend to infrastructure conditions related to water. While Mesopotamia and Egypt relied on the exploitation of water of large rivers (i.e., Tigris, Euphrates, and Nile), developments in Greece have been characterized by limited and often inadequate natural water resources. Some smaller scale rivers and lakes exist in Greece but, paradoxically, Greeks avoided the establishment of their major cities close to them. Although the reasons are not well understood, it can be hypothesized that the protection from floods and water-related diseases (e.g. malaria), as well as a more convenient life style in a dry climate were among the reasons. Water scarcity due to the dry climate and the distance from major water bodies led to the development of advanced hydraulic systems for the collection and transport of water as well as sustainable management practices.

The focus of this paper is on the technological developments and management practices related to urban water systems in the ancient Greece and their relevance to modern times. In the following sections we illustrate that such technologies were practiced as early as in the Minoan civilization and continued in a similar level in other places during the prehistoric Greek civilization, reaching a technological peak at the $6^{\text {th }}$ century $\mathrm{BC}$, well before the cultural peak in classical Athens. What is remarkable in classical Athens is the advancement made in terms of sustainable and cost efficient water management practices. A second peak, this time manifesting improved understanding of hydraulic principles, occurred during the Hellenistic period. The examples of technologies and management practices given in this article (not widely known among engineers) may have some importance for water engineering even in modern times, as discussed in the last section before the conclusions.

\section{Minoan civilization}

On the island of Crete, during the Minoan period (3500-1200 BC), an extended period of technological development occurred, related to the capture, conveyance, and utilization of 
water. Elaborate water supply systems were developed at most Minoan palaces. The types of systems varied according to local conditions and involved various aspects of water resources engineering including (1) wells and ground-water exploitation, (2) construction and use of fountains, (3) collection, storage and use of rainwater, (4) aqueducts and piping, (5) bathrooms and other sanitary facilities, and (6) even recreational uses of water.

The famous Minoan palace of Knossos is as a good example to understand the sources and methods for water supply of the Minoan period. In the first stage of the Middle Minoan period (ca. 1900-1700 BC), several wells were used for drawing drinking water. Their depth did not exceed $20 \mathrm{~m}$ and their diameter was no more than $5 \mathrm{~m}$ (Buffet and Evrard, 1950). At least six such wells have been reported (Evans, 1921-1935). The inhabitants of the Knossos palace, however, did not depend on wells alone. There are indications that the water supply system of the palace of Minos at Knossos depended on the spring water of Mavrokolybos (450 m south of the Palace) and later on the springs of Fundana and Mt. Juctas (about $10 \mathrm{~km}$ and $5 \mathrm{~km}$, respectively from the Palace). Water supply in the palace was provided through a network of terracotta piping located beneath the palace floors (Fig. 1). The pipes were constructed in sections of about 600 to $750 \mathrm{~mm}$ each. These pipes with their expertly shaped, tightly interlocked sections date from the earliest days of the building and were of quality similar to modern standards.

As evidenced from these findings, Minoan engineers had a practical knowledge of the basic hydraulic principles, which enabled them to convey water from relatively large distances in a mountainous terrain. More than 50 old aqueducts, one of which is shown in Fig. 2, have been identified in Crete (A. N. Angelakis and Y. Savvakis, unpublished report); ten were built during the Minoan period. Furthermore, hydraulic understanding was advanced enough to allow for the development and construction of fountains and a "jet d'eau" (Evans, 1921-1935), as revealed from remnants of a fresco depicting it (Fig. 3). There are no natural geysers or sulphurous boils on the island and such fountains were entirely foreign to ancient Egypt and Mesopotamia (Angelakis and Spyridakis, 1996). 


\section{Cycladic and Mycenaean civilizations}

Advanced techniques were also developed in Aegean islands during the Cycladic period (ca. 3100-1600). The archaeological investigation of the island of Thera (also known as Santorini), in the Cyclades island complex, found at least five terracotta bathtubs. All of them must have been in use until the great eruption of the Thera volcano around $1600 \mathrm{BC}$ (according to the latest chronology, Friedrich et al., 2006). There was a great variation among them. They were found in several places during the excavations; one was in a room that must have been a bathroom, equipped with an advanced sewage system (Marinatos, 1999). In Delos, another island of the Cyclades, where important remains of that period have been found, the water supply largely depended on rainwater collected and stored in cisterns. Most houses on the island had underground cisterns in their yards for stormwater storage. In addition, water from the Inopos ephemeral stream was collected in a large cistern with a length of $43 \mathrm{~m}$ and a width of 8-10 m (Papademos, 1975).

On the mainland Greece, during the Mycenaean period (1600-1100 BC), massive hydraulic works including polders, dams and artificial reservoirs for flood water retention and storage, were built (Koutsoyiannis and Angelakis, 2004). Houses in several cities, especially the luxurious ones, were equipped with bathrooms and in some cases bathtubs. The ancient Greek word " $\alpha \sigma \alpha \alpha \mu t v \theta o \varsigma$ " (asaminthos), meaning bathtub, is found in Homer's epics several times, as well as in works by later authors. A terracotta bathtub shaped like present day bathtubs, in a house in the Mycenaean Pylos, a site in south-western Peloponnesus occupied at least as early as the Middle Bronze Age is depicted in Fig. 4. Its palace compares in size and richness with the palace of Mycenae and is believed to be the home of Nestor, the second most powerful Mycenaean king. Although the bathtub was in fixed position, it must have been filled and emptied by hand rather than being connected directly to the sewers (similarly to the Minoan bathtubs). 


\section{The aqueduct of Samos: the peak of ancient hydraulic technology}

In the later archaic (750-500 BC) and classical (500-336 BC) periods, both historical sources and archaeological excavations provide evidence that urban water technologies were advanced and widespread in Greece. The advancement of urban water technology and management is illustrated in this section through the extraordinary example of the water supply of the island of Samos. The water supply system of the ancient Samos (located at the site of the modern day village of Pythagoreio) was admired both in antiquity and in modern times (Angelakis and Koutsoyiannis, 2003). The most amazing part of the water supply

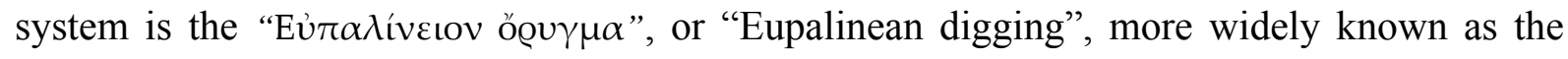
Tunnel of Eupalinos, named after the engineer from Megara who designed and constructed it. The aqueduct includes the $1036 \mathrm{~m}$ long tunnel (part NS in Fig. 5) and two additional parts (PN and SQ in Fig. 5) so that its total length exceeds $2800 \mathrm{~m}$. Its construction started in 530 $\mathrm{BC}$, during the tyranny of Polycrates and lasted ten years. It was in operation until the $5^{\text {th }}$ century AD.

Eupalinos's work is both remarkable and admirable for the following reasons.

1. He constructed the first known deep tunnel in history; shallow tunnels are much easier to construct by means of shafts and their technology was developed in earlier civilizations.

2. As done in modern construction practice, he started from two openings ( $\mathrm{N}$ and $\mathrm{S}$ ). It is evident that the two construction lines met in point $\mathrm{E}$.

3. To carve segments of the same straight line (NA and SF) from two points in a mountainous terrain, he must have had a good working knowledge of geometry and geodesy. There is evidence that Eupalinos solved the problem with simple means and in an accurate manner by walking over the mountain and putting poles up along the path in a straight line (a simple method used even today in engineering geodesy, but for simpler problems - not for the construction of tunnels). Then he lined up the workers in the tunnel segments with these poles.

4. Simultaneously, he showed that from an engineering point of view a straight line may not necessarily be the best path. Thus, at point A he left the straight line NA and followed the 
direction $\mathrm{AB}$, a plausible explanation for this being that he found a natural fracture or rift and broadening this he was able to proceed much faster (Tsimpourakis, 1997).

5. He found a clever geometrical way to eliminate the impact of uncertainty in position and direction (magnified due to already abandoning of the straight line route) and ensure the intersection of the two construction lines: By deliberately abandoning the straight line routes at points $\mathrm{D}$ and $\mathrm{F}$ and changing direction to the left and right, respectively, made it mathematically certain that the two lines would intersect (Kienast, 1995).

6. He also found an especially clever engineering solution to account for the hydraulic principle that water needs a gradient (i.e., slope) to flow. In the horizontal tunnel he achieved the necessary gradient by excavating a slopping channel along one side of the floor (Fig. 5, lower); in places where due to slope the depth of the channel would be very high, a second small tunnel below the main tunnel was built. The choice of a horizontal main tunnel was dictated by the fact that a sloping one would be impossible to construct from two sides given the technological means of the time; note that the accumulation of groundwater in the upper (viz. down-sloping) segment would not allow its construction.

It is certain that the tunnel Eupalinos constructed was not the only solution to the problem of conveying water to Samos. A simple alternative solution could have been the construction of a chain of open channels and tunnels at shallow depths with shafts, following a route around the mountain. This solution, well known already (cf. Peisistratean aqueduct; see below), would certainly have been easier technically, faster, and less expensive. The reasons that led to the construction of such a costly structure are not obvious. Probably, Eupalinos and the tyrant Polycrates preferred this unorthodox and breakthrough solution because they wished to build a monument of technology rather than simply solving a specific water transportation problem. Obviously, this solution has also the advantage of being more secure in case of war because it was not exposed to enemies. As will be discussed later, security was an essential element in Greek designs. Some authors (e.g. Apostol, 2004) suggest the security as a motivation for the choice of Eupalinos. In our opinion, this is not a sufficient reason, 
because the alternative solution of a shallow tunnel would provide same advantages (subterranean construction not exposed to enemies) in a cheaper and technically simpler way.

\section{Stream control works: the Olympia and Alyzia cases}

The protection of urban areas from the destructive action of streams (floods, erosion, sedimentation) is another case of application of hydraulic and water management technologies. Such techniques are also necessary in the development of agricultural areas given that the most fertile areas are the flood plains of rivers. As mentioned above, large scale projects (massive or Cyclopean type) of the latter type date back to the Mycenaean period. Here we present two other examples from the classical period, related to urban or suburban development: the flood protection works of Olympia and the dam of ancient Alyzia.

Olympia is one of the most important sanctuaries of antiquity, dedicated to the father of the gods Zeus (Jupiter). It is the birthplace of the Olympic Games and the place where they were held. The sanctuary of Olympia spreads around feet of the Kronion hill, where the rivers Alpheios and Kladeos meet. To control the flow of the rivers and mitigate their destructive consequences, massive walls were constructed. The Kladeos wall runs roughly the length of the ancient Olympic site, parallel to and west of it, beginning upstream at the upper end of the Gymnasium, and ending not far from the discharge of the Kladeos into the much larger Alpheios. It is a $2.7 \mathrm{~m}$ high, $800 \mathrm{~m}$ long cyclopean conglomerate, of four stone courses (Fig. 6). It has a uniform slope of approximately 0.077 . The obvious purpose for its construction was to constrain Kladeos River flow to the western side of the wall, preventing erosion of the Olympic site's western margin. Its construction date is unknown but most probably is located in the classical period, when the place took its final form (Lapp and Wright, 2003).

The ancient city of Alyzia is located in Western Greece, in the coastline of Akarnania. Close to the city, in the fringes of the Akarnanika Mountains lies a unique example of a hydraulic work of Greek antiquity: a stone dam, equipped with a stone carved lateral spillway (Fig. 7). The exact date of its construction is unknown, but because of the city's prosperity during the 5 th century $\mathrm{BC}$, this period is the most probable for the construction of the dam. 
The body of the dam has two zones. The bottom zone is characterized by more squared blocks, irregularly placed, with smaller blocks filling the gaps between them. In the upper zone, where the slope of the dam becomes softer, stones are uniformly shaped, regularly placed, with smaller gaps, which did not require filling with other, smaller stones. The structure impresses the observer with its technological and constructional overall quality. According to Murray (1984): “This is the clearest, largest, and most technologically advanced ancient specimen yet known in the whole country".

Such a structure certainly required a considerable investment from the city. Various scenarios have been expressed about the reasons that led to its construction. Most of these approaches conclude that the dam was built to collect drinking or irrigation water, or even the wash of the wool of the sheep. A recent study (Zarkadoulas, 2005), proposes a different scenario: Floods in the valley of ancient Alyzia were exceptionally intense leading to serious problems in the urban and suburban areas of the city. To mitigate the floods and withhold the coarse sediments that inundated the valley, the inhabitants of Alyzia constructed the dam in the most suitable site of the watercourse. Even today this is one of the most effective solutions for flood and sedimentation control.

The current condition of the dam is excellent. The stones by which it is composed are in their initial place and only slightly smoothed, giving us the clue that the spillway has always been operating effectively, protecting the dam from floods. The dam of ancient Alyzia is an impressive work of infrastructure not only for its scale or for the overall quality of its design and construction, but also for its continuous and successful operation for 2500 years.

\section{Water management in the city of Athens}

Athens has never had sufficient natural water resources. The two main streams, Ilisos and Kephisos have intermittent flow. Water supply has been a never-ending challenge for the city. Spring water in the area could not meet the demand, so most people relied on artificial wells for their water supply. During the excavation of ancient agora by the American School of Classical Studies at Athens, over four hundred wells were found. They represented both public and private projects. There was a great variation in depth, which ranges from 2.5 to 37 
$\mathrm{m}$, with an average of about $10 \mathrm{~m}$. In the 6th century BC, wells were occasionally lined with small-stone masonry, and, beginning in the 4th century BC, circular drums of terracotta were often used to form a shaft of great durability (Lang, 1968).

As population grew, the number of the wells increased. Solon, the Athenian statesman and poet of the late seventh and early sixth century BC, made a law about the way the water from the wells should be handled. Most of his laws have been later described by Plutarch (47-127 AD), from whom we learn:

"Since the country was not supplied with water by ever-flowing rivers, or lakes, or copious springs, but most of the inhabitants used wells which had been dug, he made a law that where there was a public well within a "hippikon," a distance of four stadia (4 furlongs, $710 \mathrm{~m}$ ), that should be used, but where the distance was greater than this, people must try to get water of their own; if, however, after digging to a depth of ten fathoms $(18.3 \mathrm{~m})$ on their own land, they could not get water, then they might take it from a neighbor's well, filling a six choae (20 L) jar twice a day; for he thought it his duty to aid the needy, not to provision the idle." (Plutarch, Solon, 23; translation adapted from Bernadotte Perrin; http://hydra.perseus.tufts.edu/).

In the 6th century BC, under the tyranny of Peisistratos (who seized power in 546 and ruled until his death in 527) and later of his sons, large public works were built. The most important hydraulic project was an aqueduct, named after him, which carried water from the foothill of the Hymettos Mountain, to the centre of the city near the Acropolis. On the outskirts of the city the aqueduct branched out to supply fountains and reservoirs. The greatest part of it was carved as a tunnel at a depth reaching $14 \mathrm{~m}$. In other parts it was constructed as a channel, either carved in rock or made from stone masonry, with a depth of 1.30-1.50 m and a width of $0.65 \mathrm{~m}$ (Papademos, 1975). In the bottom of the tunnel or channel, a pipe made of ceramic sections was placed. The pipe sections had elliptic openings in their upper part, covered by ceramic covers, for their cleaning and maintenance; the ends of the sections were appropriately shaped, so that each could be tightly fitted into the next (Fig. 8). 
Shortly after (510-508 BC), democracy was established in Athens and lasted up to 322 BC, with few intervals with oligarchic governance. During that period, no major hydraulic works were implemented, even though the need for potable water increased as the city continued to grow. What Athenians did, instead, were small scale constructions along with the development of an institutional framework for the sustainable management of water. From Plutarch's Life of Themistokles (XXXI,I), it is known that there was at least one public

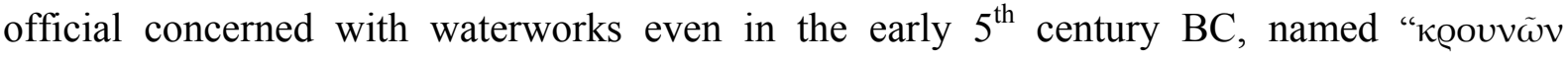
$\dot{\varepsilon} \pi \mu \varepsilon \lambda \eta \tau \eta \dot{\varsigma} "$ (i.e., Superintendent of Fountains). He was appointed to operate and maintain the city water system, to monitor enforcement of the regulation and to ensure the fair distribution of water. From Aristotle it is known that this was one of the few highest officers that were not filled by allotment but by election (Tassios, 2002). It is clear then that water management was of great importance for the city.

During the democracy period, wells were gradually complemented or replaced by cisterns. The construction of cisterns was a known practice since earlier times; for instance, several of 6th century BC have been found inside the Acropolis wall to the left of the Propylaea. Dug into the rock of the surface, with rock-cut drainage channels, they were capable of holding several months supply of water which could be used for drinking if necessary, but usually was used for bathing and cleaning (Crouch, 1993). But most of the cisterns date from the 4th to 1 st centuries $\mathrm{BC}$. The main reason of the spread of cisterns at that period must have been the gradual drop in the elevation of the groundwater aquifer due to over extraction. They were private and usually small, averaging about $3 \mathrm{~m}$ in diameter at floor level. They were filled by rainwater, collected from the surrounding roofs and directed by pipe toward the cistern mouth. Cistern water was normally used for washing and the well water for drinking (Lang, 1968).

Although during democracy several public buildings (e.g. Parthenon) with monumental character were constructed in the city, no serious hydraulic structures were implemented. A sufficient explanation can be obtained from Aristotle:

"... and it must possess if possible a plentiful natural supply of pools and springs, but failing this, a mode has been invented of supplying water by means of constructing an 
abundance of large reservoirs for rainwater, so that a supply may never fail the citizens when they are debarred from their territory by war." (Aristotle, Politics, III, I330b; translation from http://hydra.perseus.tufts.edu/)

Another reason for the absence of major hydraulic projects during the democracy period, as opposed to the period of tyranny (cf. Polycrates and Peisistratos), must be the fact that all decisions were taken democratically. Thus, it is probable that Athenians would be reluctant to fund large-scale projects of this kind. The extent and the cost of the solutions chosen had to be in absolute accordance with the actual needs and the general economic status of the city.

Later, when the Romans took control of the city, water became a matter of luxury and prestige. Public water systems grew and aqueducts were used to transfer water to public fountains. The most important structure of this period was an aqueduct, built under the reign of emperor Hadrian (117-138 AD), conveying water from mountains Parnes and Pentele to Athens, covering a distance of $25 \mathrm{~km}$. This new aqueduct supplied the Athenians large quantities of high quality potable water. The increased supply completely changed the way the Athenians handled water, as can be inferred from the larger overflow pipes constructed in this period (Lang, 1968). Private installations like wells and cisterns tended to be abandoned, signifying a water management attitude different from the classical period.

\section{The Hellenistic period and the Pergamon aqueducts}

The Hellenistic period (323-146 BC) is characterized by significant progress in mathematics (particularly geometry), physics, and technology (e.g. Koutsoyiannis and Angelakis, 2003). The well-known water helix pump invented by Archimedes (287-212 BC), is a characteristic example of how geometry, combined with understanding of physics (gravity and hydraulics) aided technological advances. Particularly in Alexandria, significant developments were done in hydraulics, which allowed the invention of advanced hydraulic and pneumatic instruments and devices (such as pumps, hydraulic clocks, musical instruments, steam boilers and a reactive motor). All of these developments reflect a good understanding of the combined 
action of air and water pressure and particularly the function of a siphon and an inverted siphon.

There are indications that the flow under pressure was known much earlier than this period, such as in the Minoan period (cf. the jet d'eau described above). However, the Hellenistic period seems to be the first in history in which the pressure flow was applied on large technological scale for water conveyance. The characteristic example is the water supply system of the citadel of Pergamon. The ancient city of Pergamon is in western Anatolia (today Turkey), $30 \mathrm{~km}$ inland from the Aegean Sea. Little is known of the city's history before the Hellenistic period. The dynasty of the kingdom of Pergamon began with General Philetairos (283-263 BC) and ended in $133 \mathrm{BC}$ with its surrender to the Romans on the death of the last king, Attalos III (Ministry of the Aegean and University of Athens, 2006).

The first settlement of the town was on top of the high hill. The water needs of the city were met by rainwater stored in a system of cisterns (providing secure water supply in the event of war) and by a small spring at the foot of the hill. By 1993, 149 such cisterns had been found, which could support a population of about 7900 inhabitants (Garbrecht and Garbrecht, 2005). The city began to expand and around 200 BC water demand exceeded the locally available water resources. Three aqueducts were installed to transfer water from the mountains. One aqueduct, transferring water from the Madradag Mountain, crossed the depression north of City Hill as an inverted siphon of length exceeding $3 \mathrm{~km}$ with a maximum pressure head of about $180 \mathrm{~m}$ (Fig. 9). The inverted siphon was made of metal (lead) and anchored with big stone constructions (Garbrecht et al,. 2001). A sediment settling chamber was built at the upstream end of the inverted siphon to prevent it from being obstructed by sediments (Garbrecht and Garbrecht, 2005). The great length of the construction and above all the unbelievably high pressure head, both of which make any alternative (e.g. water bridge) infeasible, is certainly a milestone of hydraulic engineering.

\section{Relevance to modern times}

To put in perspective the ancient water management principles and practices discussed in this paper, it is important to examine their relevance to modern times and to harvest some lessons 
learned. The relevance of ancient works will be examined in terms of the evolution of technology, technological advances, design principles, and management principles.

The Evolution of Technology An important question to discuss is whether modern water technologies were derived form ancient Greek technological achievements or were Greek achievements totally forgotten (during dark ages) and had to be re-invented in modern times. The latter thesis could be regarded as an extension of Crouch's (1993, p. 123) thinking about the evolution of technologies in ancient times. Specifically, she states: "Because of the gap in the archaeological record, we cannot be sure whether any of their (e.g. the Mycenaeans and Minoans) knowledge about water management survived the collapse of these civilizations and the 400 years or so of the 'Dark Ages' that followed. [...] we would not expect them [sophisticated technologies] to survive but to be independently re-invented when later Greek society reached technological sophistication."

The evolution of science and engineering is not linear but rather characterized by discontinuities and regressions. On the other hand, it is not "Markovian" in the sense that only the present (i.e. the state at a certain time instant) and not the past (i.e. the entire history) influences the future. "Bridges" from the past to the future are always present, albeit some times invisible in the present. Thus, in addition to many constructions that have been continuously or intermittently in operation up to present day, written information from ancient Greece has survived (including even detailed contracts between the public and constructors of hydraulic works; Koutsoyiannis and Angelakis, 2003). A characteristic example for such a "bridge" comes from astronomy: The heliocentric model of the solar system was first formulated by the astronomer Aristarchus of Samos (310-230 BC), who also figured out how to measure the distances to and sizes of the Sun and the Moon. For years it was thought that Copernicus re-invented this theory 1800 years later. Now we know that Copernicus was aware of Aristarchus's theory, since his original draft of De Revolutionibus has survived and features a passage referring to Aristarchus which Copernicus crossed out (Weisstein, 2006).

The tunnel of Eupalinos and its two lines of construction also was not forgotten over long

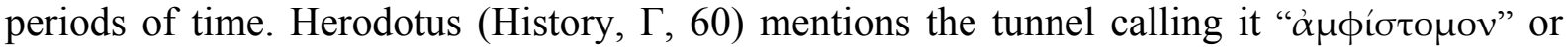
"bi-mouthed", indicating that it was constructed from two openings. Four centuries after 
Eupalinos, the mathematician and physicist Hero (Heron) of Alexandria (Dioptra, II; 1st century BC), inspired by this tunnel, studied the problem how "to dig a mountain on a straight line from two given mouths" (his geometrical Problem \#15; see also Apostol, 2004). The solution he proposed which is based on a route around the mountain, is technologically inferior to that of Eupalinos - but the most essential is that the importance of the problem and the feasibility of its solution passed to the next generations and the history.

Hero was himself an engineer and together with his predecessor Alexandrian engineers Ctesibius and Philon Byzantius, and the Syracusean mathematician, engineer and philosopher Archimedes, offered the foundation and the basic applications of hydrostatics and hydrodynamics (Koutsoyiannis and Angelakis, 2003). As discussed above, the development of such a scientific framework in the Hellenistic period was a scientific basis of the pressure aqueduct in Pergamon. In this case it has been maintained that no other inverted siphon of this size has been built for one and a half millennium thereafter (Garbrecht and Garbrecht, 2005), which may be interpreted as a case of discontinuity in the history of technology. However, this may be disputable because the Roman engineer Vitruvius describes the inverted siphon (Hodge, 2002) and because siphons (perhaps of smaller size) were found in Roman aqueducts of later periods, for instance in Lugdunum (Lyon; Screen, 2005). Other advances of this period were in continuous use through the centuries. The most characteristic example is Archimedes's helix pump, which is used still today from large scale engineering applications (e.g. in wastewater and storm drain pumping stations) to medical procedures (e.g. in surgery to maintain blood circulation).

Technological Advances: What Progress? Another issue that must be examined is the comparison of hydraulic technology in ancient times to that in modern times. Certainly many modern advances were not known in the antiquity such as the use of plastic and concrete pipes, the automated pressurized urban water distribution systems, the use of electromechanical equipment such as pumps, and the effective mechanical equipment for the construction of hydraulic works. But to some extent these are differences in the apparatus and the scale of applications and not differences of fundamental principles used. Even the life style related to the hygienic standards of the civilization may not be a recent development. For 
example, flushing toilets equipped with seats resembling present day toilets and drained by sewers existed from the Minoan times (e.g. in the Knossos palace; Angelakis et al., 2005). The essential progress of modern times is the better understanding and mathematization of hydraulics which allows better design and management of hydraulic works and much larger scales of application.

Design Philosophy Current day engineers typically use a design period of structures of about 40 to 50 years, which is related to economic considerations. Sustainability, as a design principle, has entered the engineering lexicon within the last decade. It is difficult to infer the design principles of ancient engineers. Nevertheless, it is notable that several ancient works have operated for very long periods, until contemporary times. For example, water for the modern city Athens was supplied primarily by the Hadrianian aqueduct up to 1920s and partly until the 1950s. The Peisistratean aqueduct is still in operation today (with some interruptions, the most recent being caused two years ago by a damage from the construction of a modern underground car park) albeit not for water supply but for the irrigation of the National Garden in the center of Athens. Athens can be regarded as an example of a sustainable city given that its history extends for more than 3000 years (even though the city's sustainability, livability and beauty have worsened in the second half of the $20^{\text {th }}$ century). Despite frequent earthquakes and war actions, several constructions have survived up to present reflecting the grandeur of the city's history.

With the events of the past few years, security of infrastructures is now a concern for every country. However, because in the recent past security has not been considered properly, many urban water supply systems are vulnerable in case of war or terrorist actions or in case of natural disasters. Yet, the concern for security was a critical element of the system design philosophy in ancient times, as discussed above. For example, the entire Peisistratean aqueduct in Athens was constructed as an underground aqueduct, so that it was not exposed and its route not known to aliens. No such considerations were made in the modern aqueduct of Athens, constructed in the second half of the $20^{\text {th }}$ century (Fig. 10). The stormwater cisterns, whose maintenance in ancient Athens must have been obligatory for citizens, is another provision for maximization of the system stability and safety. In addition to providing 
a source of water for private use and enhancing the security of the overall system, cisterns (still in wide use in anhydrous Greek islands) also reduce the amount of storm water to be discharged.

Lately, interventions such as the use of cisterns are being reassessed and are currently recommended as storm water source control practices (Maksimovic and Tejada-Guibert, 2001). In modern Athens such storm water tanks would partly mitigate the flood problem (Xanthopoulos et al., 1996; Koutsoyiannis, 2000) but they do not exist.

Management Principles The Athenian example described earlier manifests admirable balances between (a) structural and nonstructural (institutional) measures; (b) large scale (e.g. the Peisistratean aqueduct) and small scale (wells and cisterns) projects; and (c) interests of the public (for large scale works) and the private (for small scale works) sectors. The latter is apparent even in Solon's regulation discussed above, whose ultimate purpose was to balance public and private interest for the construction and operation of wells. Today, similar solutions are often sought both in developed and developing countries as neither the public nor the private sector alone can provide sustainable solutions for water supply (Maksimovic and Tejada-Guibert, 2001). In modern Athens, the responsibility for the management of the water supply system was initially assigned to the municipality and the central government, then (in the 1920s) it passed to a private company, which about 50 years later became a public organization that was re-privatized six years ago; some municipalities in the Athens area still play some role in water supply management. These forward and backward changes clearly indicate that such a balance between private and public interests has been not established to date.

\section{Conclusion and discussion}

Beginning from Minoan Crete, fundamental technologies regarding water supply were developed in ancient Greece to a degree never reached prior to that time (Viollet, 2003). Using these technologies, impressive urban water supply systems appear to have been implemented, initially without regard to cost criterion consideration. As a result, the water supply systems represent the state-of-the-art that was technically feasible at that time. 
Similarly, the aqueduct of ancient Samos is an important hydraulic monument, proving that it was absolutely feasible in the ancient world to design and construct technologically advanced water transportation projects on a large scale.

Athenians, on the other hand, especially during the golden period of the city, seem to have fully adapted urban water management principles to deal with the limited water resources, following a rather advanced model, which included large scale public works (constructed earlier, during tyranny) but was mainly based on small-scale constructions (cisterns and wells) and non-structural measures (Solon's laws, institutions such as Superintendent of Fountains) imposing a remarkable balance of public and private interests. It is evident that the system of democratic Athens must have worked exceptionally well for a long period. This approach is remarkably advanced, as modern water resource policymakers and hydraulic engineers are now re-emphasizing the importance of nonstructural measures and small-scale structural measures in urban water management (Maksimovic and Tejada-Guibert, 2001; Angelakis and Koutsoyiannis, 2003).

Excavations at several other cities of Greek antiquity have brought to light urban water systems equally advanced to those described in this paper. The achievements of ancient Greece in dealing with the hygienic and functional requirements, related hydraulic technologies and water management practices can only be compared to modern urban water systems, re-established in Europe and North America from the second half of the $19^{\text {th }}$ century $\mathrm{AD}$ (Angelakis et al., 2005) until present day. It is reasonable to assume that with a few exceptions, the basis for present day progress in urban water management is clearly not a recent development.

From the above discussion, it is useful to reflect on some lessons learned from past history:

- The meaning of sustainability in modern times should be reevaluated in light of ancient public works and management practices.

- Technological developments based on sound engineering principles can have extended useful lives.

- Security, with respect to water, is of critical importance in the sustainability of a population. 
- In water-short areas, development of an effective water resources management program is essential.

Acknowledgements The encouraging comments and suggestions by two anonymous reviewers and the editor resulted in significant improvement of this article.

\section{References}

Angelakis, A. N., Koutsoyiannis, D., and Tchobanoglous, G. (2005). "Urban wastewater and stormwater technologies in Ancient Greece.” Water Research, 39(1), 210-220.

Angelakis, A. N., and Koutsoyiannis, D. (2003). "Urban Water Resources Management in Ancient Greek Times." Stewart, B.A. and T. Howell, T., eds., The Encyclopedia of Water Science, 999-1007, Dekker, New York, 2003.

Angelakis, A. N., and Spyridakis, S. V. (1996). "The status of water resources in Minoan times: A preliminary study.” Angelakis A. N. and Issar, A.S., eds., Diachronic Climatic Impacts on Water Resources with Emphasis on Mediterranean Region. Springer-Verlag, Heidelberg, Germany, pp. 161-191 (Chapter 8).

Apostol, T. M. (2004). “The Tunnel of Samos.” Engineering and Science, 67(1), 30-40.

Buffet, B., and Evrard, R. (1950). L'Eau Potable a Travers Les Ages. Editions Soledi, Liege, Belgium.

Crouch, D. P. (1993). Water Management in Ancient Greek Cities. Oxford University Press, New York - Oxford.

Evans, S. A. (1921-1935). The palace of Minos at Knossos: A comparative account of the successive stages of the early Cretan civilization as illustrated by the discoveries. Vols. I-IV, Macmillan and Co., London, UK (Reprinted in 1964 by Biblo and Tannen, New York, USA).

Friedrich, W. L., Kromer, B., Friedrich, M., Heinemeier, J., Pfeiffer, T., and Talamo, S. (2006). "Santorini Eruption Radiocarbon Dated to 1627-1600 B.C.", Science, 312(5773), 548 (DOI: 10.1126/science.1125087) 
Garbrecht, G., Brinker, W., Fahlbusch, H., Hetch, K., and Thies, H. (2001). "Die Wasserversorgung von Pergamon." Altertumer von Pergamon, Band 1: Stadt und Landschaft, Teil 4, Deutsches Archaeologisches Institut AvP I.4, herausgegeben im Auftrag des Institutes von Wolfgang Radt, Verlag Walter de Gruyter, Berlin/New York.

Garbrecht, J. D., Garbrecht, G. K. H. (2005). "Water Supply Challenges and Solutions of the Ancient City of Pergamon", Proceedings of Oklahoma Water 2005, Paper \#6, Oklahoma Water Resources Research Institute, Stillwater, OK, 5 pp.

Hodge, A. T. (2002). "Roman waterworks (G. De Kleijn: The Water Supply of Ancient Rome: City Area, Water, and Population)", The Classical Review, 52(02), 346-348 (doi: $10.1093 / \mathrm{cr} / 52.2 .346)$

Kienast, H. J. (1995). Die Wasserleitung des Eupalinos auf Samos, Deutches Archäologisches Institute, Bonn.

Koutsoyiannis, D. (2000). "Urban water systems management: Remarks - questions opinions", Water and Environment, Water Supply and Sewerage Company of Athens, Athens, Greece (in Greek).

Koutsoyiannis, D., and Angelakis, A. N. (2004). "Agricultural hydraulic works in ancient Greece", Stewart, B.A. and Howell, T., eds., Encyclopedia of Water Science, New York, N.Y., USA (DOI: 10.1081/E-EWS-120020412).

Koutsoyiannis, D., and Angelakis, A. N. (2003). "Hydrologic and hydraulic science and technology in ancient Greece", Stewart, B. A. and Howell, T., eds., The Encyclopedia of Water Science, 415-417, Dekker, New York, 2003 (DOI: 10.1081/E-EWS-120016393).

Lang, M. (1968). "Waterworks in the Athenian Agora", Excavations of the Athenian Agora Picture Book No. 11, American School of Classical Studies at Athens, Connecticut, USA.

Lapp, R. J. and Wright, K. R. (2003). “Olympia Floods Sedimentation”, WPI Technical Report, Wright Paleohydrological Institute (WPI), Denver, Colorado.

Maksimovic, C., and Tejada-Guibert, J. A. (eds.) (2001). Urban Water Management Deadlock or Hope, IWA Publishing, London. 
Marinatos, S. (1999). Excavations at Thera VI-VII, 1972-1973 Seasons (Second Edition), The Archaeological Society at Athens, Athens, Greece.

Ministry of the Aegean and University of Athens (2006). Archaeological Atlas of the Aegean (http://www.ypai.gr/atlas/Default_uk.asp\#)

Murray, W. M. (1984). "The ancient Dam of the Mytikas Valley", American Journal of Archaeology, 88(2), 195-203.

Xanthopoulos, Th., Christoulas, D., Mimikou, M., Aftias, M., and Koutsoyiannis, D. (1996) "Flood protection of the Athens basin", Monthly Technical Review, 48, 50-53 (in Greek).

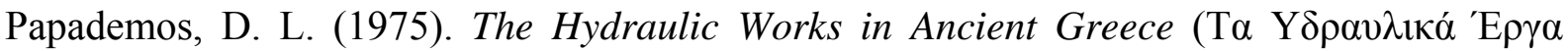

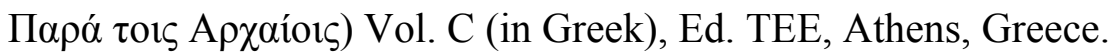

Screen, B. M. (2005). "Around the Roman world in 180 days", MsA thesis, University of South Africa (http:/etd.unisa.ac.za/ETD-db/theses/available/etd-06122006-142238/ unrestricted/dissertation.pdf)

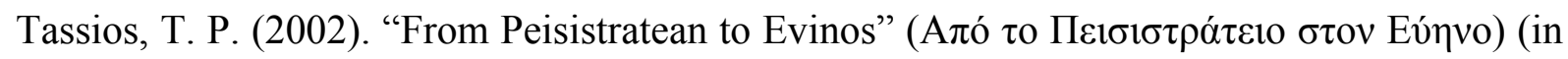
Greek). Kathimerini, 24 March 2002, Athens, Greece.

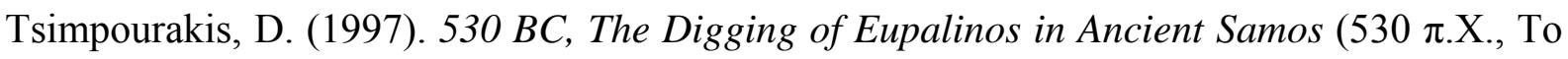

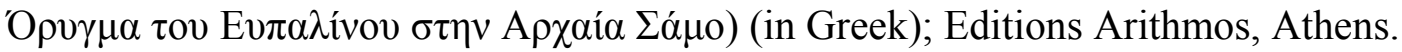

Viollet, P.-L. (2003). "The Predecessors of European Hydraulic Engineers: Minoans of Crete and Mycenaeans of Greece (2100-1200 BC).” XXX IAHR Congress, Theme E: Linkage Between Education Research and Professional Development in Water Engineering. August 2003, Thessaloniki, Greece.

Weisstein, E. W. (2006). Copernicus, Nicholaus, in World of Biography, (http://scienceworld.wolfram.com/biography/Copernicus.html).

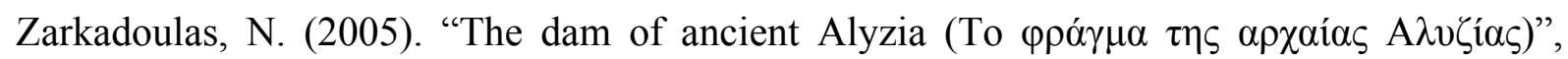
Postgraduate Thesis, 94 pages, Department of Water Recourses, Hydraulic and Maritime Engineering - National Technical University of Athens, Athens (in Greek). 


\section{Figure captions}

Figure 1 Minoan water supply pipes (terracotta pipe sections): cross section and dimensions (upper) and modern view (lower; by courtesy of M. Nikiforakis, Hellenic Photographic Association of Crete, Iraklio, Greece).

Figure 2 Parts of the aqueduct in the Tylissos archaeological site: central conduit (left) located in the entrance of the three villas and before the little cistern and secondary conduit, and small lithic cistern (right), probably used for removal of suspended solids of water before its storage to the main cistern.

Figure 3 Remnants of the fresco showing the Minoan fountain (jet d'eau) from the "House of Frescos" of the Knossos palace (Archaeological Museum of Iraklio, Greece).

Figure 4 Terracotta bathtub in fixed position in Mycenaean Pylos (by courtesy of Z. Philip Ambrose, from "The Ambrose Collection", Univ. of Vermont Classics Dept.; http://www.uvm.edu/\%7Eclassics/ mainpagelinks/ambrose.html).

Figure 5 The Tunnel of Eupalinos: longitudinal section (upper), horizontal plan view (middle), and view of the tunnel and the sloped channel (and at points second tunnel below the main tunnel) on the right side (lower, by courtesy of Tracey Rihll, from "Greek and Roman Science and Technology", http://www.swan.ac.uk/classics/staff/ter/grst/images/tunnelatitsbest.jpg).

Figure 6 The Wall Blocks of Kladeos stream in ancient Olympia (by courtesy of Ken Wright, from Lapp and Wright, 2003).

Figure 7 The dam of Alyzia; the spillway with its irregular shape formed by erosion through centuries is shown on the right of left photo and in operation in the right photo. 
Figure 8 Parts of the Peisistratean aqueduct uncovered during the recent excavations for the Metro of Athens, as shown: (left) in place near the Syntagma Metro Station; (right) in a show box in the Evangelismos Metro Station.

Figure 9 Sections of the Madradag aqueduct at Pergamon: (upper) longitudinal section indicating the $3 \mathrm{~km}$ long inverted siphon; (lower) typical cross section showing an anchor stone of the leaden pipe (dimensions in meters; sections constructed by data in Garbrecht et al., 2001).

Figure 10 The modern Athens aqueduct near the Delphi Oracle site (by courtesy of Leonardos Michas, Water Supply and Sewerage Company of Athens. 


\section{Figures}
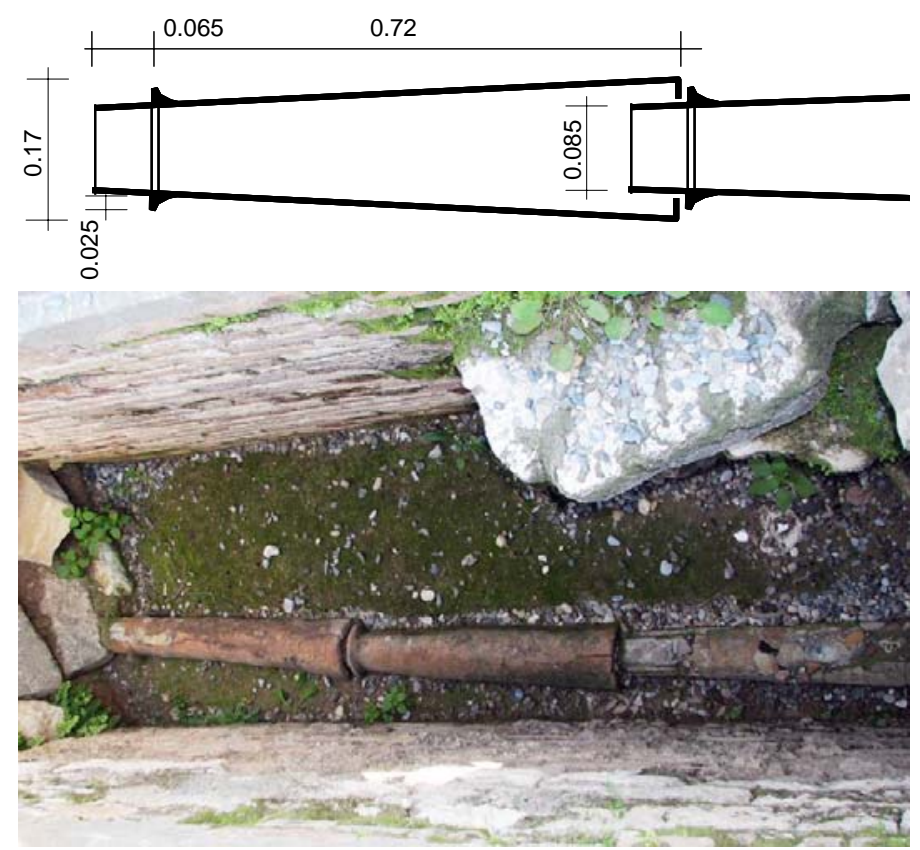

Figure 1 Minoan water supply pipes (terracotta pipe sections): cross section and dimensions (upper) and modern view (lower; by courtesy of M. Nikiforakis, Hellenic Photographic Association of Crete, Iraklio, Greece). 

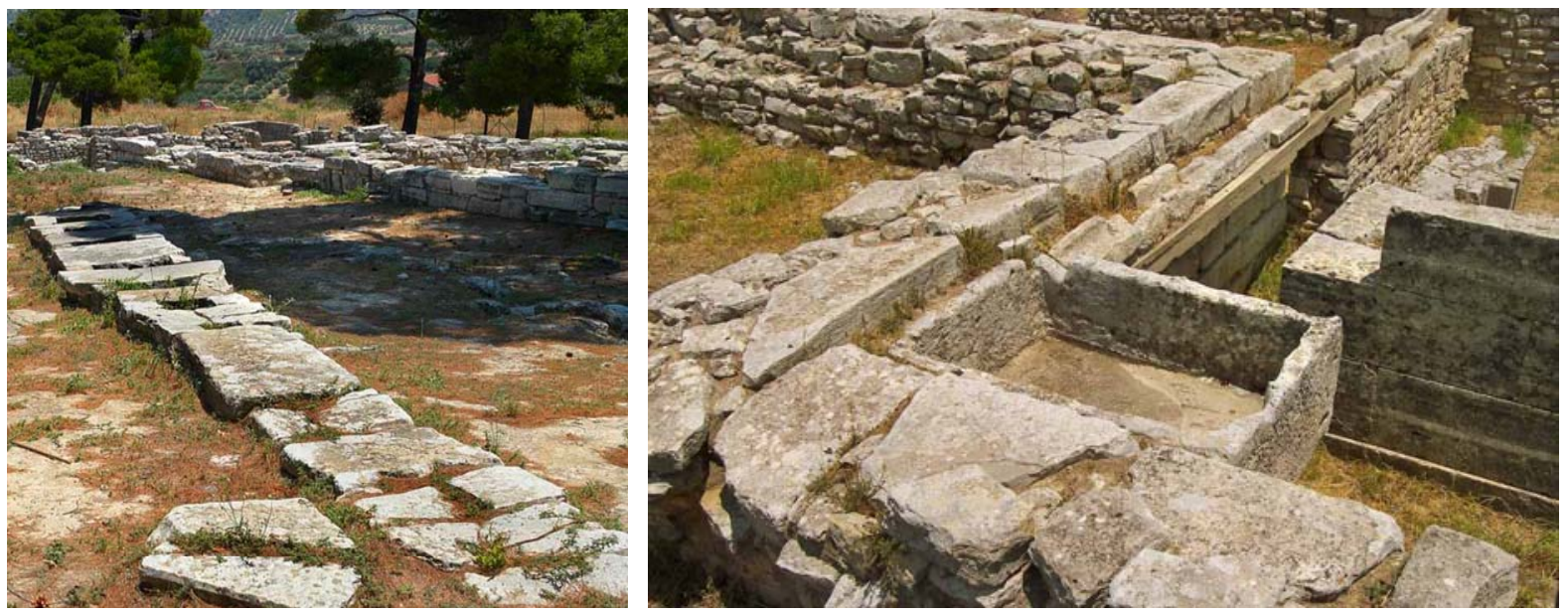

Figure 2 Parts of the aqueduct in the Tylissos archaeological site: central conduit (left) located in the entrance of the three villas and before the little cistern and secondary conduit, and small lithic cistern (right), probably used for removal of suspended solids of water before its storage to the main cistern. 


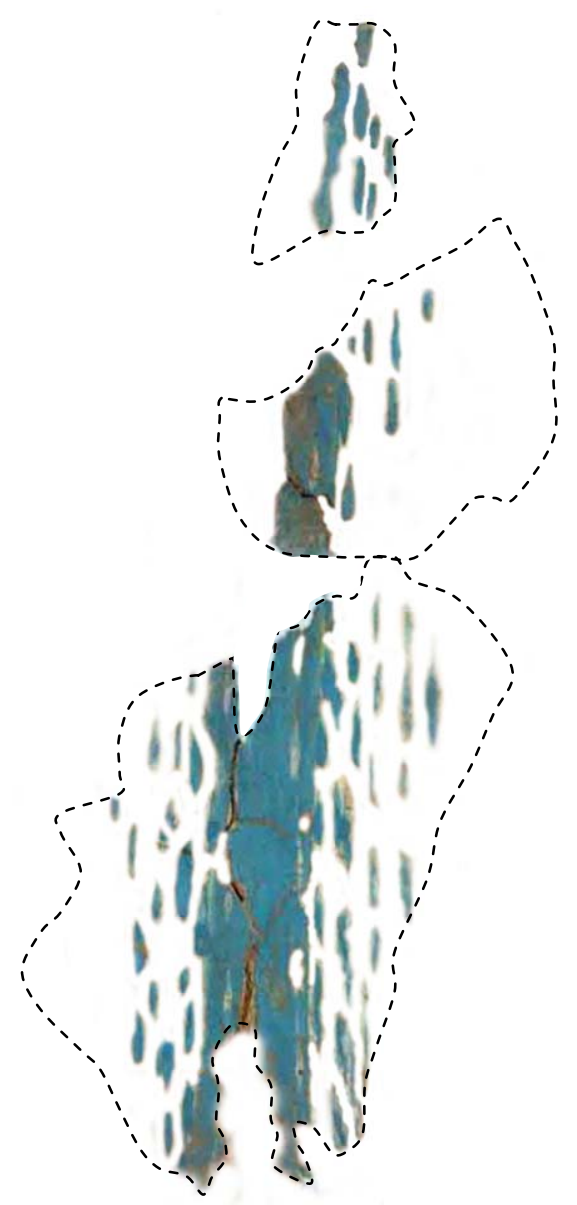

Figure 3 Remnants of the fresco showing the Minoan fountain (jet d'eau) from the "House of Frescos" of the Knossos palace (Archaeological Museum of Iraklio, Greece). 


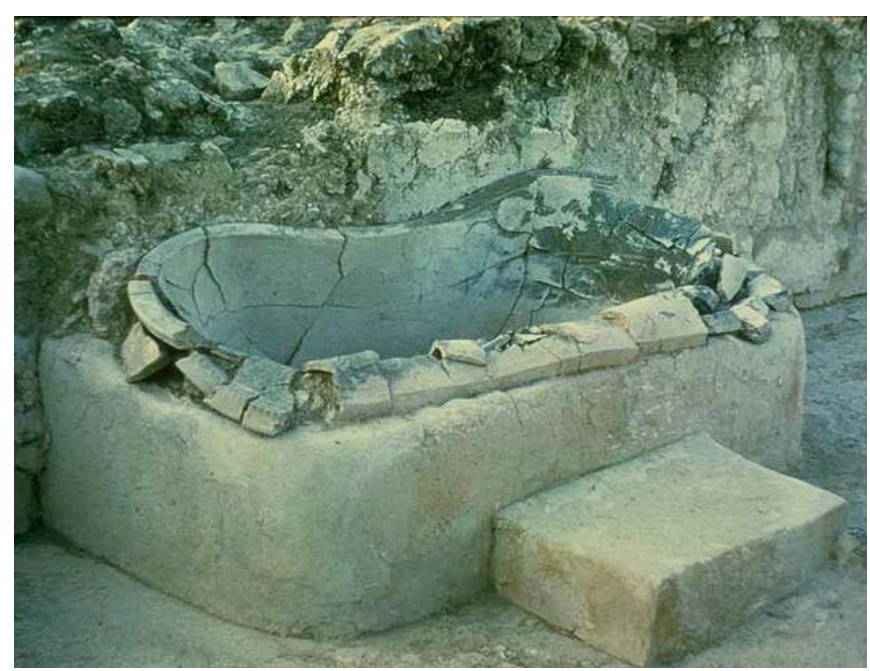

Figure 4 Terracotta bathtub in fixed position in Mycenaean Pylos (by courtesy of Z. Philip Ambrose, from "The Ambrose Collection", Univ. of Vermont Classics Dept.; http://www.uvm.edu/\%7Eclassics/ mainpagelinks/ambrose.html). 

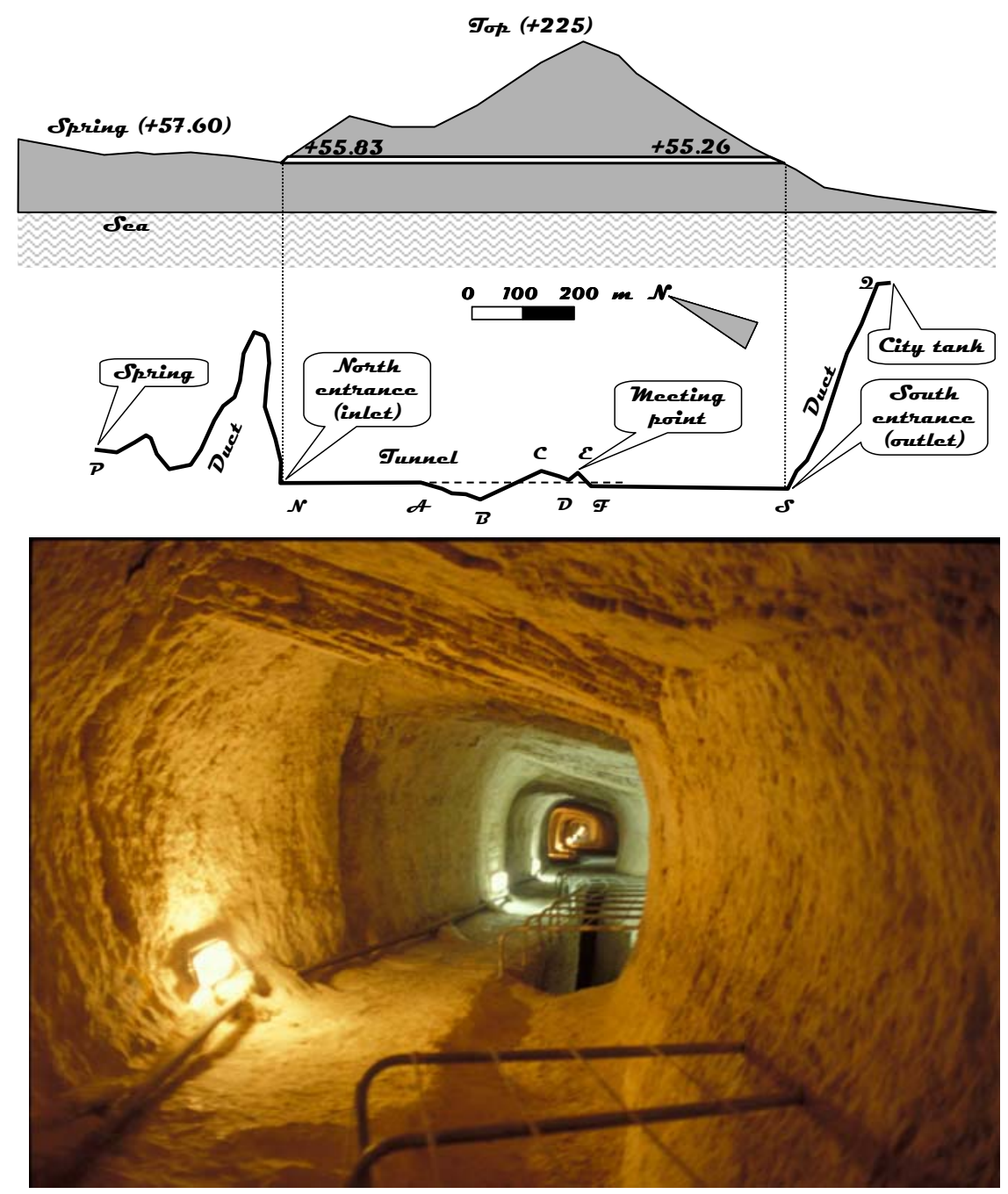

Figure 5 The Tunnel of Eupalinos: longitudinal section (upper), horizontal plan view (middle), and view of the tunnel and the sloped channel (and at points second tunnel below the main tunnel) on the right side (lower, by courtesy of Tracey Rihll, from "Greek and Roman Science and Technology",

http://www.swan.ac.uk/classics/staff/ter/grst/images/tunnelatitsbest.jpg). 


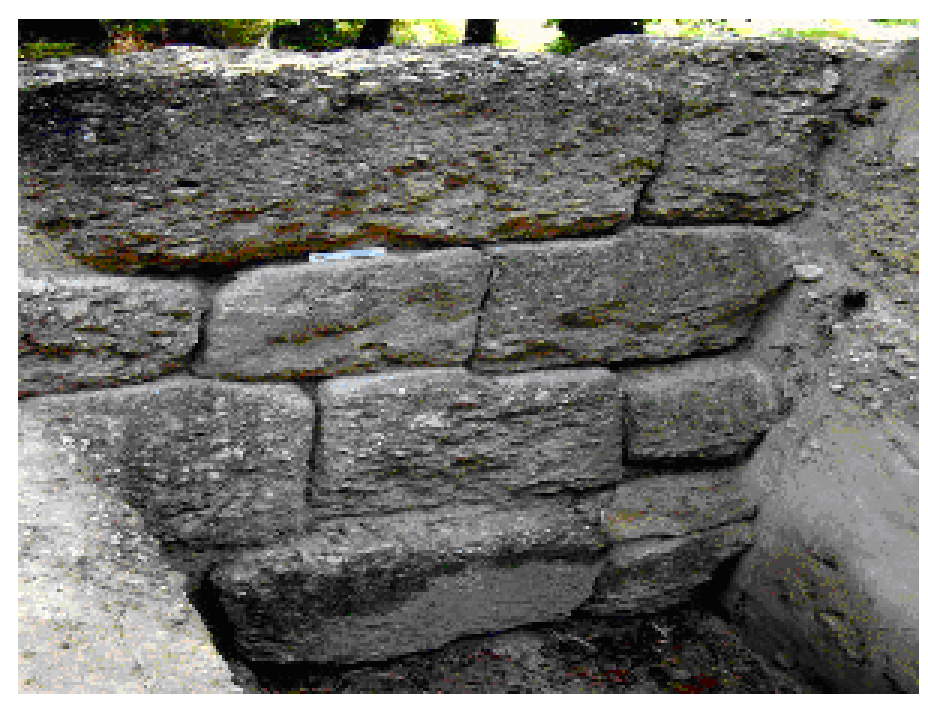

Figure 6 The Wall Blocks of Kladeos stream in ancient Olympia (by courtesy of Ken Wright, from Lapp and Wright, 2003). 

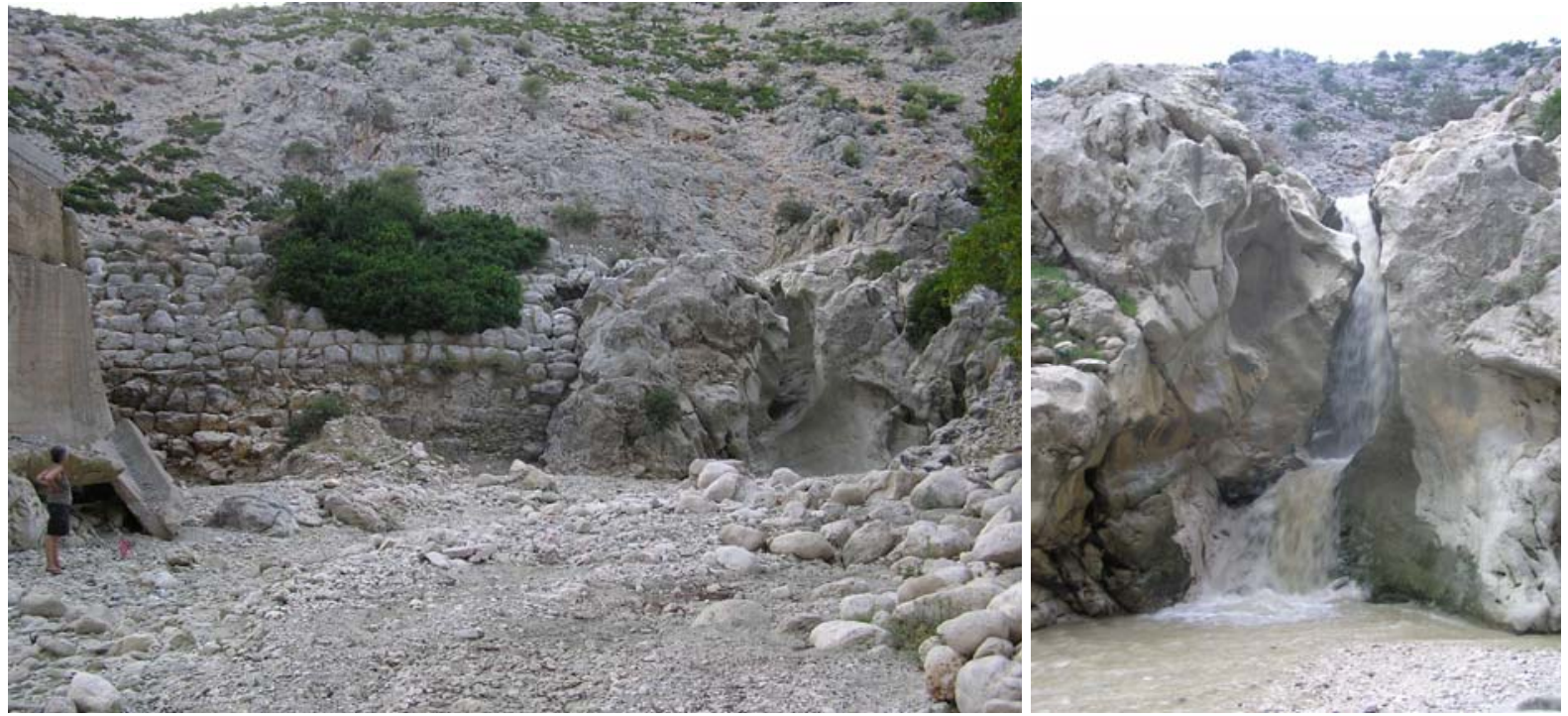

Figure 7 The dam of Alyzia; the spillway with its irregular shape formed by erosion through centuries is shown on the right of left photo and in operation in the right photo. 

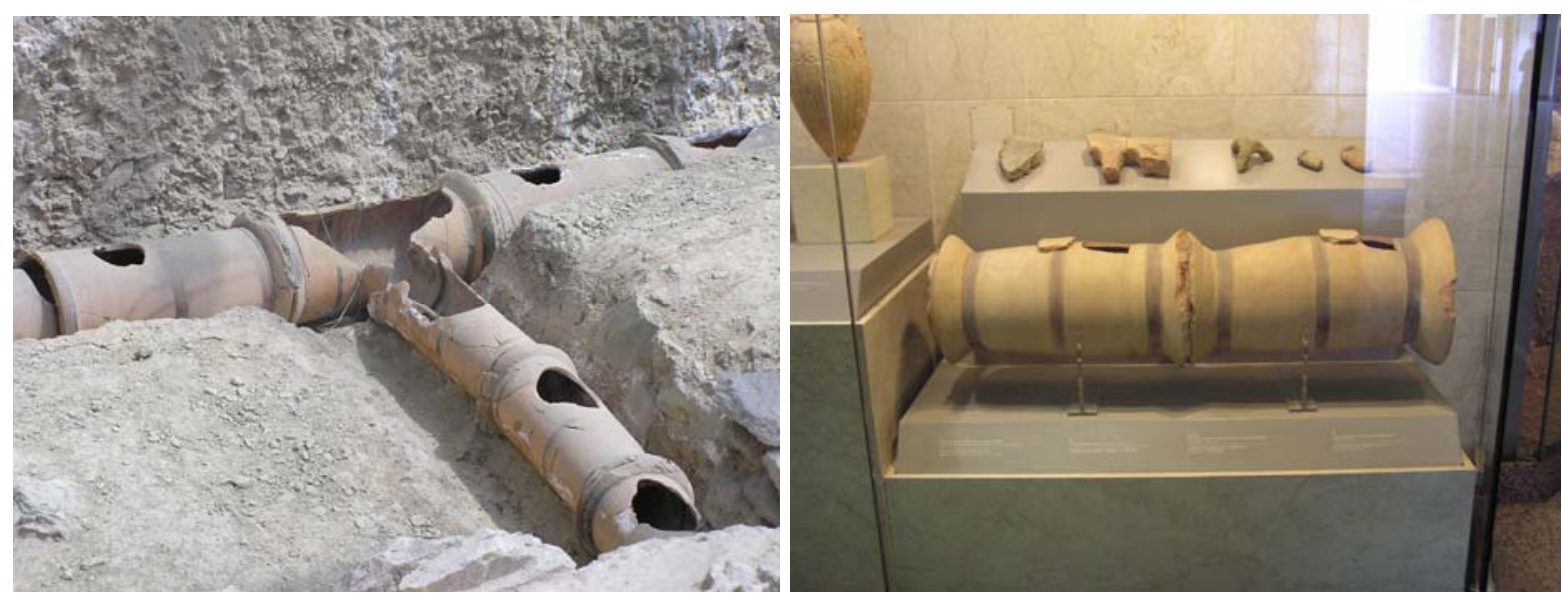

Figure 8 Parts of the Peisistratean aqueduct uncovered during the recent excavations for the Metro of Athens, as shown: (left) in place near the Syntagma Metro Station; (right) in a show box in the Evangelismos Metro Station. 

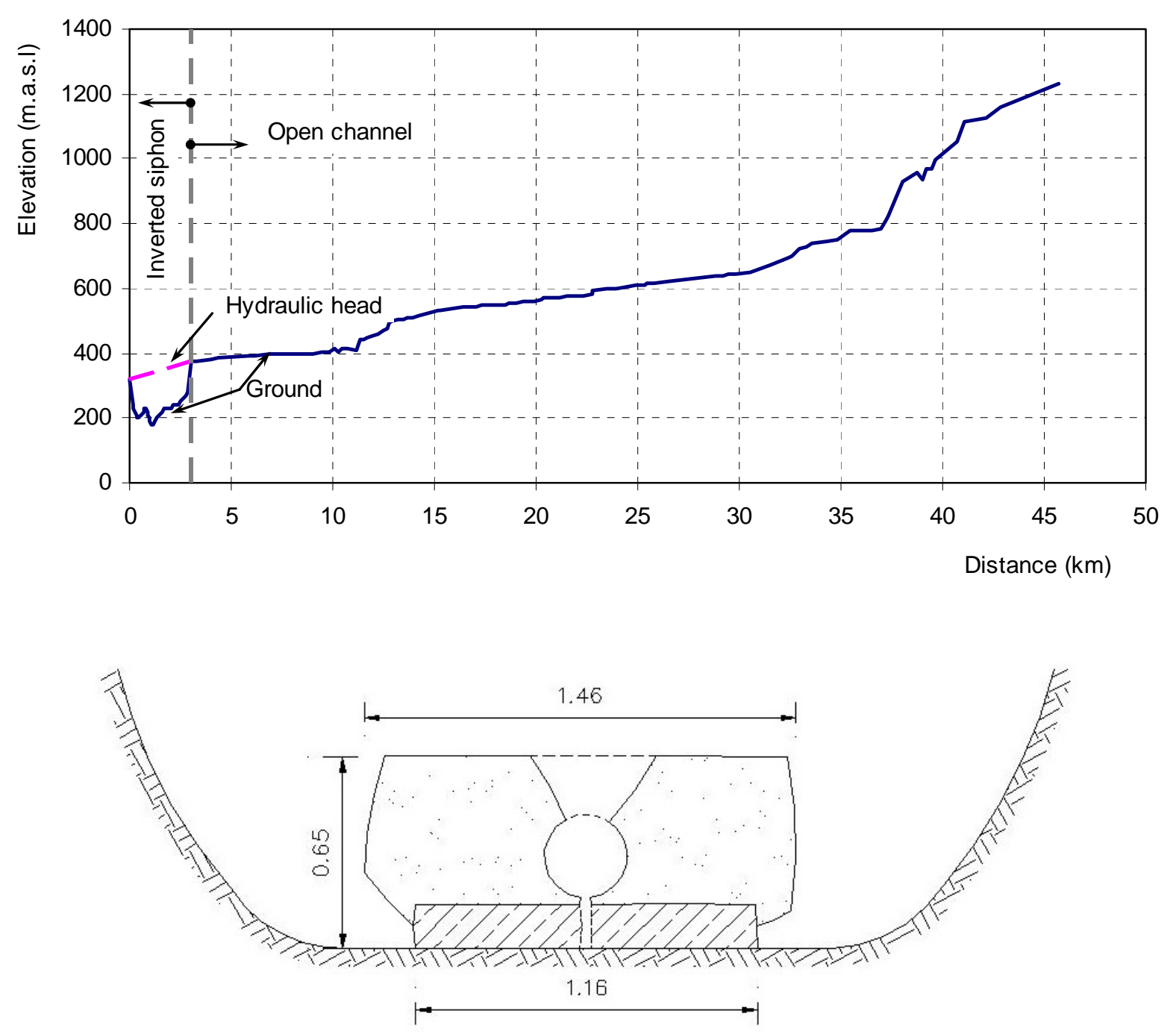

Figure 9 Sections of the Madradag aqueduct at Pergamon: (upper) longitudinal section indicating the $3 \mathrm{~km}$ long inverted siphon; (lower) typical cross section showing an anchor stone of the leaden pipe (dimensions in meters; sections constructed by data in Garbrecht et al., 2001). 


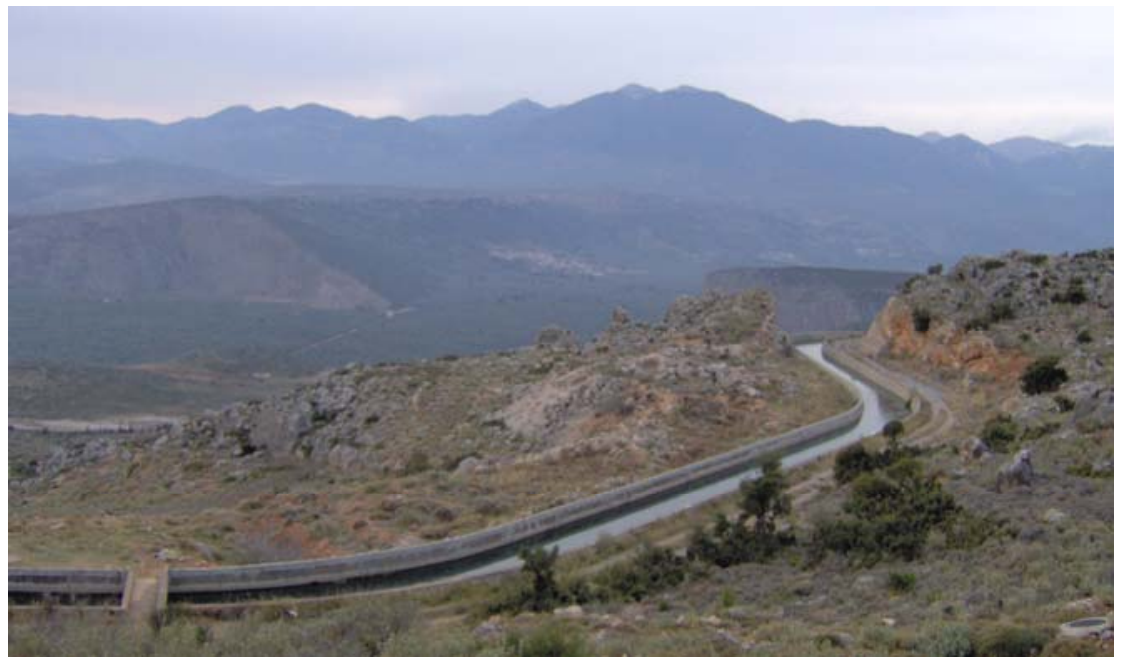

Figure 10 The modern Athens aqueduct near the Delphi Oracle site (by courtesy of Leonardos Michas, Water Supply and Sewerage Company of Athens. 